\title{
MINISTÉRIO DA AGRICULTURA
}

\author{
FAISCAÇÃO E GARIMPAGEM - LAVRA CLANDESTINA
}

\begin{abstract}
- Se o que se faz nas jazidas de curo de Piancó, atualmente, é a faiscação, a despeito das autorizaçóes de pesquisa, transformada em lavra clandestina, a solução está em reconhecer-se a situação de fato existente, pondo-a de acôrdo com as disposições legais que regulam a faiscação.
\end{abstract}

EXPOSIÇÃO DE MOTIVOS G. M. N. 323

\section{Exmo. Sr. Presidente da República}

A descoberta de ricas jazidas de ouro em terras de propriedade particular, situadas no município de Piancó, no Estado da Paraíba, de fácil exploração pelo processo rudimentar da faiscação num momento em que o precioso metal é pago por preço jamais atingido em moeda nacional, drenou, como era notural, para aquela região de país, intermitentemente assolada pelas sêcas, onde o trabalho é difícil de obter e geralmente mal remunerado, grandes levas do nordestinos, atraídos pela perspectiva do ganho fácil e impulsionados pelo espírito de aventura que o meio físico tornou característica dos habitantes da região.

Os candidatos à faiscação, entretanto, são, na sua grande maioria, gente sem recursos de qualquer espécie, o que, impedindo-os de adquirir os instrumentos necessários para o início dos trabalhos, deixa-os à mercê dos que estão nas condições de tornar-lhes possível a formação do "soco", como pitorescamente designam, na região, o aparelhamento do faiscador ou garimpeiro incipiente. Dêste modo ficam os garimpeiros, desde logo, num regime de quase servidão, em proveito daqueles por conta de quem vão minerar, os quais assim se fazem pagar da insignificante assistência inicialmente prestada, mas não sem violação flagrante da legislaçãa de minas, nos dispositivos que regulam a faiscação e a garimpagem.

O capitalista, precavidamente, requer ao Govêrno autorização para pesquisar a jazida e de posse do respectivo decreto, com exclusão de quaisquer outros concorrentes, entra a explorar a jazida por todos os meios possíveis, menos aquêle a que devia cingir-se em obediência aos preceitos do Código.

Embora só the seja permitido, por fôrça do título de autorização de pesquisa, executar os trabalhos necessários para o descobrimento da jazida e o conhecimento de seu valor econômico, utilizando o produto da pesquisa para fins de estudos do minério e custeio dos trabalhos, divide a área da jazida em banquetas, que vende ou arrenda a terceiros, por conta dos quais passam a trabalhar os faiscadores, quando não thes explora o trabalho diretamente, a jornal ou em parceria sob condiçōes leoninas, enriquecendo-se sem outro esfôrço além do de receber o produto extraído.

As jazidas de Piancó, que deviam estar em pesquisa e não em exploração, produziram em menos de dois anos, por semelhante processo, por cima de tonelada e meia de ouro fino, ou seja quantia que se avizinha de Cr\$ 40.000.000,00, da qual os faiscadores não participaram senão em ínfima percentagem, quando, por lei, êles nāo poderiam ter menos de $90 \%$ (noventa pot cento). 
Tal perspectiva de lucro fácil a custo do trabalho alheio teria naturalmente que provocar o desencadeamento de lutas, pela competição entre os candidatos à percepção de tal vantagem.

Expedidos os Decretos de autorização de pesquisas referentes às jazidas de ouro de Piancó aos que os requereram de acôrdo com o que prescreve o Código de Minas, começaram a surgir reclamações de uns contra outros, acusando-se reciprocamente de violaçóes dos dispositivos do Código, assim como dos direitos dos que reclamavam. Agravando-se a situação, resolvi designar uma comissão de funcionários do Departamento Nacional de Produção Mineral para verificar in loco o que se estava passando e o resultado da diligência, na qual participaram dois engenheiros de minas e um assistente juridico, foi a confirmação de que as autorizações de pesquisa eram pretextos para o estabelecimento do monopólio, em proveito dos respectivos titulares, da exploração intensiva das jazidas de outo por milhares de trabalhadores, nelas colocados como faiscadores, a trabalhar por conta dos titulares das autorizações, em lavra clandestina, e com infringência, portanto, não sòmente dos preceitos da legislação de minas que regulam a faiscação e a garimpagem, como dos que regulam as autorizaçōes de pesquisas e lavra.

Diante de tal situação, cabia ao Govêrno promover a anulação das autorizações de pesquisa, se se tratasse apenas de resolver a questão nos seus aspectos formais. Não são, porém, sòmente êsses os aspectos que o Govêrno tem de levar em conta para resolver a situação, pôsto que outros, de muito maior relevância, nos seus aspectos, se apresentem a pedir solução imediata.

O Sr. Consultor Jurídico do Ministério, estudando a matéria, focalizou os vários aspectos em que esta se apresenta, nas seguintes passagens de seu parecer n. ${ }^{\circ} 1.413$, emitido no processo D. N. P. M. 8.986-42.

"Por essas informações, colhidas in loco, vê-se que os pedidos de autorização de pesquisa no Nordeste são simples pretextos para a lavra clandestina, por processos rudimentares, das jazidas de minérios de alto valor econômico, convertendo-se as áreas autorizadas em campos de garimpagem, essa mesma desvirtuada pelos titulares das autorizaçóes.

Ao Govêrno Federal cabe tomar providências rápidas e enérgicas para fazer cessar tão perniciosa prática, comprometedora da própria preservação das jazidas. Infelizmente, o caso não se apresenta apenas sob o aspecto legal, fàcilmente solucionável com a simples aplicação ao titular das autorizaçóes dos dispositivos do Código de Minas, pois muito mais séria é a questão social que
envolve.

Não creio que o regime de autorização de pesquisa e lavra possa ser aplicado no Nordeste como estabelece o Código de Minas, sempre que estiverem em causa metais ou minérios de alto valor econômico, suscetiveis de serem extraídos pelos processos de faiscação, garimpagem ou cata, forma de tratamento que dâ rendimento imediato e é de fácil acesso aos que se vêem obrigados a abandonar a sua atividade normal na pequena lavoura acossados pelo flagelo das sêcas cu impelidos pelo espírito de aventura atrás de lucros fáceis. Não admitindo a fase de pesquisa senão moderada extração de minérios, proporcionará trabalho a muito poucas, pessoas, mas nem os flagelados ou ambiciosos esperam, nem os titulares das pesquisas pensam em lavrar a jazida com obediência ao que prescreve o Código de Minas, o que exige muito tempo consumido e a inversão de grandes capitais, improdutivos até que a jazida entre em lavra. Os requerentes de autorizaçóes de pesquisas querem apenas obte: do Govêrno a privilegiada situação de titulares de um decreto que os autoriza a ocupar a jazida e extrair minétios na execução dos trabalhos de pesquisas, a que dão a elasticidade que podem. 
Mas se assim se apresenta a questão ao Govêrno, melhor é que êste the dê a solução que a atende ao mesmo tempo em seus aspectos legal e social, este muito sério para que seja pôsto à margem ou relegado para um segundo plano.

Ao meu ver, salvo naturalmente os casos de exceçäo que comportarem autorizações de pesquisa requeridas com a ânimo de serem levadas a têrmo, as jazidas de ouro e depósitos minerais de alto valor econômico, situados no nordeste, devem ser reservados aos trabalhos de faiscação e garimpagem, sob rigorosa fiscalização do D. N. P. M., para evitar as deturpações costumeiras".

Estando de acôrdo com o Sr. Consultor Jurídico do Ministério nas considerações acima transcritas, solicito a Vossa Excelência autorização para as tornar efetivas.

O Código de Minas, mesmo quando se trate de jazida pesquisadas, admite a recusa pelo Govêrno da respectiva lavra, se esta fôr considerada prejudicial ao bem público ou comprometer interêsses que superem a utilidade da exploração industrial a juizo do Govêrno, ficando o pesquisador, neste último caso, com o direito de receber do Govêrno a indenização das despesas feitas com os trabalhos de pesquisa, uma vez que haja sido aprovado o relatório (art, 36 ).

As jazidas de ouro de Piancó têm sido apenas objeto de autorizações de pesquisa, com as deturpações apuradas pelos técnicos do D. N. P. M. que a vistoriaram por ordem minha. Normalmente, deverá o Govếrno promover a anulação das autorizações, pela forma prescrita no art. 26 do Código de Minas. Isso requereria, entretanto, a perda do tempo necessário para o processo administrativo que teria de ser instaurado. E' evidente, porém, que se ao Govêrno é facultado negar a autorização de lavra, depois da jazida ser considerada oficialmente pesquisada; nos casos previstos no citado art. 36 do Código de Minas, com maioria de razão poderá o Govêrno cassar as simples autorizações de pesquisa, nos mesmos casos.

O que se está passando nas jazidas de ouro de Piancó é prejudicial ao bem público, não sòmente no que diz respeito à preservação das mesmas jazidas qưe são bens da Nação, ameaçadas que estão de ficarem prejudicadas pela natureza dos trabalhos de extração do ouro atualmente empregados, como no que diz respeito à defesa dos interêsses dos milhares de trabalhadores nelas localizados, sujeitos a um regime contrário ao prescrito pelo Código de Minas para a faiscação e a garimpagem.

$O$ aspecto juridico e social que o caso apresenta ficarão atendidos, cassando o Govêrno as autorizaçōes de pesquisas já expedidas, por prejudiciais ao bem público, e declarando zona de garimpagem aquela em que estiverem localizadas as jazidas. A fim de que sejam fielmente cumpridas as disposições legais que regulam a faiscação e a garimpagem, tomará o Govêrno providências no sentido de permanecerem na região técnicos do $D$. N. P. M. que fiscalizem e orientem os trabalhos, assim como de representantes do Banco do Brasil, a quem seja entregue todo o ouro extraído pelos faiscadores. Uma vez comprado o ouro pelos preços oficiais do líquido, serão pagos dez por cento aos proprietários dos terrenos, em obediência ao presente no art. $62,810^{\circ}$, do Código de Minas, e o restante entregue ao faiscador, como propriedade que é, dêle, adquirida com o seu trabalho. Aos trabalhadores que se apresentarem sem recursos para o início dos trabalhos, adiantará o Govêrno ou o Banco do Brasil êsses recursos indenizando-os os faiscadores com o produto extraído, na forma que fôr julgada em melhores condições de consultar os interêsses recíprocos.

Sendo o Govêrno, ex-vi legis, o comprador privativo de todo o ouro produzido nas minas e jazidas do país, por um lado, e cabendo-lhe, por outro lado, 
prestar assitência social ao trabalho, não é demais que a preste por aquela forma, numa época em que a economia dirigida é uma das funções do Estado.

O que tenho a honra de propor a Vossa Excelência dará forma legal, dentro dos mais rigorosos princípios de moral e de justiça, a uma situação, de fato, infringente da legislação do país, com preterição dos direitos dos que produzem em benefício dos que se limitam a gozar dêsse benefício. Se o que se faz nas jazidas de ouro de Piancó, atualmente, é a faiscação, a despeito das autorizações de pesquisa, transformada em lavra clandestina, parece-me que a solução está em reconhecer-se a situação, de fato, existente, pondo-a de acôrdo com as disposições legais que regulam a faiscação.

Aproveito a oportunidade para reiterar a Vossa Excelencia os protestos do meu mais profundo respeito.

Rio de Janeiro, 7 de março de 1944." - Apolonio Sales.

Aprovado. Em 16-3-44 . - G. VARGAs. 